\title{
UPAYA PEMERINTAH DALAM MENGKOMUNIKASIKAN TRADISI MALAMANG MENJADI OBJEK PARIWISATA BUDAYA DI KABUPATEN PADANG PARIAMAN
}

\author{
Yudhistira Ardi Poetra*), Ernita Arif**), Zainal Arifin***) \\ Universitas Andalas, Padang, Indonesia \\ yudhistira_ardi@ymail.com*) arifernita@yahoo.co.id ${ }^{* *}$ ) arifinzed@gmail.com***) \\ Naskah diterima: 3 Mei; direvisi: 10 Mei; disetujui: 17 Mei
}

\begin{abstract}
Abstrak
Tradisi malamang merupakan suatu budaya yang telah tumbuh dan berkembang di lingkungan masyarakat. Tradisi malamang di Padang Pariaman memiliki potensi untuk dijadikan objek pariwisata budaya oleh pemerintah. Upaya Pemerintah Kabupaten Padang Pariaman untuk mengkomunikasikan tradisi malamang menjadi objek pariwisata budaya dapat dilakukan dengan mengorganisasi pesan atau informasi mengenai tradisi malamang ke masyarakat. Penelitian ini menggunakan teori integrasi informasi. Penelitian ini menggunakan metode deskriptif kualitatif dengan pendekatan etnografi public relations. Objek penelitian ini adalah tradisi malamang sebagai pariwisata budaya. Dalam penelitian ini, yang menjadi informan adalah pihak-pihak dari pemerintah yang berkaitan dengan upaya pemerintah dalam mengkomunikasikan tradisi malamang menjadi objek pariwisata budaya di Kabupaten Padang Pariaman. Sumber data penelitian ini diperoleh dari data primer dan data sekunder. Penelitian ini menggunakan teknik pengumpulan data dengan cara observasi, wawancara, kajian pustaka, dan dokumentasi. Di dalam penelitian ini, diuraikan upaya pemerintah dalam mengkomunikasikan tradisi malamang menjadi objek pariwisata budaya di Kabupaten Padang Pariaman. Kegiatan malamang tidak hanya berkaitan dengan budaya dan ajaran spiritual, melainkan memiliki nilai sosial, kerjasama, dan komunikasi antara komunitas masyarakat dan Pemerintah Daerah dalam pandangan etnografi komunikasi. Pemerintah Kabupaten Padang Pariaman memberikan pengetahuan tentang tradisi malamang kepada pelajar sebagai upaya komunikasi kepada generasi muda. Pemerintah Kabupaten Padang Pariaman melihat adanya potensi pariwisata pada tradisi malamang, tetapi belum memulai untuk mengkomunikasikannya kepada masyarakat.
\end{abstract}

Kata kunci: pariwisata budaya, tradisi malamang, etnografi komunikasi, dan upaya pemerintah.

\begin{abstract}
Malamang tradition is a culture that has grown and developed in the peoples. Night Tradition in Padang Pariaman has potential to be the object of cultural tourism by the government. Goverment of Padang Pariaman Regency's to be a cultural tourism object, it can be done by organizing messages or information about the nighttime tradition to the peoples. This research uses information integration theory. This research uses descriptive qualitative method with public relations ethnography approach. The object of this research is malamang tradition as cultural tourism. In this research, the informants are the employees from the government who related to the government's efforts in communicating the malamang tradition into the object of cultural tourism in Padang Pariaman Regency. Sources of this research data are found from primary data and secondary data. This research uses data collection techniques by observation, interviews, literature review, and documentation. In this research, decribed government's efforts
\end{abstract}


in communicating the malamang tradition into the object of cultural tourism in PadangPariaman Regency. Malamang activities are not only related to culture and spiritual teachings, but have social values, cooperation and communication between the community and local government in the ethnographic view of communication. Padang Pariaman Government provides knowledge about the malamang tradition to students as a communication effort to the young generation. Padang Pariaman Government sees the potential of tourism in malamang tradition, but has not yet started to communicate to the public. Keywords: cultural tourism, malamang tradition, ethnography of communication,
government's efforts

\section{Pendahuluan}

Kekayaan jenis makanannya merupakan cermin keberagaman budaya dan tradisi Nusantara yang terdiri dari sekitar ribuan pulau yang dihuni oleh ratusan suku, dan menempati peran penting dalam budaya nasional Indonesia secara umum. Salah satu makanan tradisional yang ada di Indonesia adalah lemang. Lebih dari sekedar makanan, di Sumatera Barat, lemang yang oleh masyarakat di sana dikenal dengan lamang juga tampil sebagai makanan yang masuk ke dalam sebuah tradisi, yaitu malamang atau membuat lamang. Tradisi ini sudah menjadi perayaan turun-temurun bagi masyarakat yang dilaksanakan setiap tahunnya. Tidak ada informasi valid kapan pertama kali tradisi malamang ini dilaksanakan oleh masyarakat Minangkabau, akan tetapi tradisi ini sudah disebarkan dari mulut ke mulut dari generasi ke generasi hingga saat ini.

Tradisi malamang memiliki kemiripan dengan grebeg kraton yang ada di Yogyakarta. Kedua kegiatan budaya ini sama-sama diselenggarakan pada saat Maulid Nabi. Akan tetapi, keikutsertaan pemerintah dalam mengembangkan potensi wisata daripada dua kegiatan budaya ini memiliki perbedaan cukup signifikan. Kalau di Padang Pariaman kegiatan malamang belum dijadikan sebagai objek pariwisata budaya oleh pemerintah. Sedangkan di Yogyakarta, Pemerintah Daerah Yogyakarta sudah berhasil menjadikan grebeg kraton menjadi destinasi pariwisata budaya. Grebeg kraton banyak diminati oleh masyarakat oleh berbagai daerah sebagai destinasi wisata pada saat Maulid Nabi.

Keikutsertaan pemerintah dapat membantu untuk mengkomunikasikan tradisi malamang kepada seluruh masyarakat baik lokal maupun nasional. Public relations atau Humas yang dimiliki oleh pemerintah dapat menjembatani apa yang ingin dilakukan oleh pemerintah dengan apa yang diharapkan oleh masyarakat agar tradisi malamang ini terus menerus akan tetap ada hingga generasi-generasi berikutnya. Ini dikarenakan humas lembaga pemerintah, yakni "merupakan suatu keharusan fungsional dalam rangka tugas penyebaran informasi kebijakan, program dan kegiatan-kegiatan lembaga pemerintah kepada masyarakat" (Rahmadi, 1999: 77).

Upaya Pemerintah Kabupaten Padang Pariaman mengkomunikasikan tradisi malamang menjadi objek pariwisata budaya dapat dilakukan dengan mengorganisasi pesan atau informasi mengenai tradisi malamang ke masyarakat. Pengorganisasian informasi ini biasa disebut dengan integrasi informasi, yang mana pelaku komunikasi berpusat pada cara kita mengakumulasikan dan mengatur informasi tentang semua orang, objek, situasi, dan gagasan yang membentuk sikap atau kecenderungan untuk bertindak dengan cara yang positif atau negatif terhadap beberapa objek (Little John, 2009:111). Jadi, pemerintah dapat mengatur informasi mengenai tradisi malamang ini agar muncul sikap kepedulian masyarakat akan pelestarian tradisi malamang.

Berdasarkan pemikiran tersebut, penelitian ini bertujuan untuk menjelaskan etnografi komunikasi dalam kegiatan malamang di Kabupaten Padang Pariaman. selain itu, penelitian ini secara khusus bertujuan untuk menjelaskan upaya Pemerintah Kabupaten Padang Pariaman dalam mengomunikasikan tradisi malamang kepada generasi muda dan upaya Pemerintah Kabupaten Padang Pariaman dalam mengkomunikasikan tradisi malamang menjadi objek pariwisata budaya. 
Manfaat praktis dari penelitian ini adalah untuk memberikan masukan dan dapat dijadikan acuan serta informasi bagi masyarakat khususnya Minangkabau agar lebih kenal dengan budayabudaya sekitar khususnya malamang. Selain itu, peneliti berharap hasil penelitian ini dapat membantu Pemerintah Kabupaten Padang Pariaman dalam meningkatkan potensi tradisi malamang yang rutin dilakukan masyarakat menjadi sebuah objek pariwisata budaya yang dapat menambah pendapatan daerah. Sedangkan manfaat teoritis penelitian ini yaitu memberikan kontribusi, memperluas, dan berguna bagi pengembangan pengetahuan dalam bidang ilmu komunikasi, khususnya etnografi komunikasi.

Sejauh yang dapat diketahui, penelitian, baik yang dipublikasikan dalam bentuk laporan penelitian, jurnal, artikel ilmiah, buku tentang upaya pemerintah dalam mengkomunikasikan tradisi malamang menjadi objek pariwisata budaya di Kabupaten Padang Pariaman belum ada yang melakukan. Akan tetapi, beberapa tulisan yang sudah membahas kajian mengenai pelestarian budaya, etnografi komunikasi, dan pariwisata budaya sudah ada yang melakukan dan dapat digunakan sebagai bahan bandingan untuk kajian ini. Beberapa tulisan tersebut antara lain adalah Hidayat (2017), Karthago (2014), Zulfa dan Kaksim (2014), dan Alus (2014). Semua tulisan ini menampilkan fakta bahwa perlu adanya keikutsertaan pemerintah dalam melestarikan suatu tradisi. Selain itu, beberapa tulisan mengemukakan bahwa pemerintah daerah dapat mengembangkan suatu kegiatan kebudayaan pada daerah mereka menjadi sebuah tujuan wisata budaya yang dikunjungi oleh wisatawan dari luar daerah.

Penelitian ini menggunakan beberapa konsep dan teori, yaitu komunikasi, public relations, etnografi komunikasi, dan teori integrasi informasi. Komunikasi merupakan hal yang paling penting dilakukan pemerintah dalam mengomunikasikan tradisi malamang sebagai objek pariwisata budaya di Kabupaten Padang Pariaman. Public relations merupakan bagian dari pemerintah yang sangat berperan aktif dalam upaya pemerintah melestarikan tradisi malamang dan dan upaya pemerintah dalam mengkomunikasikan tradisi malamang sebagai objek pariwisata budaya di Kabupaten Padang Pariaman. Etnografi komunikasi digunakan untuk melihat bagaimana pendekatan budaya yang dilakukan oleh Humas Kabupaten Padang
Pariaman beserta beberapa dinas, yaitu Dinas Pendidikan dan Kebudayaan, Dinas Pariwisata Pemuda dan Olahraga, dan Dinas Pemberdayaan Masyarakat dan Desa sebagai fokus perhatian yang di dalamnya terdapat unsur budaya dan komunikasi sebagai upaya pemerintah dalam mengkomunikasikan tradisi malamang sebagai objek pariwisata budaya di Kabupaten Padang Pariaman. Sedangkan teori integrasi informasi digunakan dengan cara melihat penyebaran informasi yang dilakukan pemerintah dengan public relation-nya dalam upaya melestarikan tradisi malamang melalui dinas-dinas yang ada di bawahnya dan berbagai media komunikasi seperti koran, majalah, tabloid, website, media sosial, dan iklan-iklan di berbagai media.

\section{Metode}

Secara keseluruhan, penelitian ini merupakan jenis penelitian deskriptif kualitatif yaitu menggambarkan tentang upaya pemerintah dalam mengkomunikasikan tradisi malamang menjadi objek pariwisata budaya di Kabupaten Padang Pariaman dan menggunakan pendekatan etnografi public relations.

Dalam penelitian ini, yang menjadi objek penelitian adalah tradisi malamang sebagai pariwisata budaya. Lokasi yang dipilih untuk penelitian adalah instansi Pemerintah Kabupaten Padang Pariaman, meliputi Humas Pemerintah Daerah Kabupaten Padang Pariaman, Dinas Pendidikan Kabupaten Padang Pariaman, Dinas Pariwisata dan Pemuda Olahraga, serta Dinas Pemberdayaan Masyarakat dan Desa. Selain itu, peneliti juga melakukan pengamatan di Daerah Toboh dan Pauh Kamba, Padang Pariaman yang melakukan kegiatan tradisi malamang.

Pada penelitian ini peneliti menggunakan teknik pengumpulan data dengan cara observasi, wawacara, kajian pustaka, dan dokumentasi. Dalam observasi, peneliti mengamati langsung bagaimana keikutsertaan pemerintah dalam kegiatan tradisi malamang dengan menjadi bahagian dari masyarakat di Toboh, Padang Pariaman. Kemudian, peneliti melakukan wawancara dengan mengajukan pertanyaan terbuka yang terstruktur kepada informan penelitian yang sudah ditentukan. Selain itu, peneliti menggunakan buku-buku dan beberapa artikel yang ada di majalah, koran, atau di internet yang masih berkaitan dengan upaya pemerintah dalam mengkomunikasikan tradisi malamang sebagai objek pariwisata budaya di Kabupaten 
Padang Pariaman sebagai literatur untuk penelitian ini. Yang terakhir, peneliti mendokumentasikan setiap kegiatan tradisi malamang, wawancara dengan informan, dan mengumpulkan gambar dari situs resmi Kabupaten Padang Pariaman dan media online sebagai bukti sah peneliti melakukan penelitian.

Dalam penelitian ini, peneliti akan menggunakan metode analisa data etnografi public relations. Metode ini menggunakan teknik analisis data yang umum digunakan pada metode etnografi komunikasi. Teknik analisis data meliputi reduksi, deskripsi, dan interpretasi. Peneliti mengolah data dengan membuat transkrip hasil wawancara maupun transkrip atas catatan hasil observasi yang telah dilakukan selama penelitian. Setelah itu, peneliti membuat beberapa data penting yang menjawab tujuan penelitian yang sudah dirumuskan. Kemudian, peneliti menganalisa, dan mengonfirmasi data tersebut berdasarkan teori yang sudah ditentukan.

\section{Hasil dan Pembahasan}

\subsection{Tradisi Malamang di Kabupaten Padang Pariaman dalam Etnografi Public Relations}

Tradisi malamang merupakan suatu budaya yang telah tumbuh dan berkembang di lingkungan masyarakat. Hingga saat ini belum ada data valid kapan pertama kali tradisi malamang ini mulai dilaksanakan oleh masyarakat. Akan tetapi, mayoritas masyarakat Padang Pariaman sangat percaya bahwa Syekh Burhanuddin mengenalkan malamang ini kepada masyarakat saat dirinya menyiarkan agama islam di daerah Ulakan. Masyarakat percaya bahwa malamang merupakan salah satu metode dakwah yang diperkenalkan oleh Syekh Burhanuddin kepada masyarakat di Ulakan, Padang Pariaman, pada saat beliau mengenalkan agama Islam yang pada saat itu masyarakat di sana mayoritas masih beragama Hindu.

Kegiatan dari tradisi malamang yang masih rutin dilaksanakan oleh masyarakat di sekitar Kabupaten Padang Pariaman pada saat sekarang ini adalah pada saat peringatan Maulid Nabi Muhammad SAW dan upacara kematian seperti mendoakan anggota keluarga yang baru saja meninggal dunia. Pada dasarnya, malamang sebenarnya bukanlah acara utama pada kegiatan Maulid Nabi, maupun upacara kematian. Akan tetapi, setiap acara tersebut diselenggarakan, masyarakat wajib membuat lemang atau malamang.

Peringatan Maulid Nabi di Kabupaten Padang Pariaman memiliki sebuah keunikan. Di sana, perayaan Maulid Nabi tidak hanya dilakukan di satu hari dan satu tempat. Perayaan Maulid Nabi bisa dirayakan saat sebelum peringatan Maulid Nabi yang jatuh pada 12 Rabiul Awal atau ketika kelahiran Nabi Muhammad SAW, ketika peringatan Maulid Nabi, dan setelah peringatan Maulid Nabi. Setiap korong atau dusun tidak boleh mengadakan malamang pada tanggal yang sama. Inilah yang membuat perayaan Maulid Nabi di Kabupaten Padang Pariaman dapat berlangsung selama dua sampai tiga bulan.

Kegiatan malamang dilakukan oleh masyarakat di Kabupaten Padang Pariaman pada saat hari pertama dari tiga hari perayaan Maulid Nabi. Pada hari tersebut, pada pagi harinya masyarakat yang terdiri dari laki-laki dewasa dan beberapa anak yang diajak membantu pergi mencari bambu dan kayu bakar untuk memasak lamang. Di rumah, para ibu-ibu dibantu oleh anak perempuan mereka di setiap rumah mulai memasak bahan-bahan untuk isian lamang. Setelah bambu dan kayu bakar sudah dapat, bahan-bahan tadi dimasukkan ke dalam bambu dan dibakar pada sore hingga malam harinya.

Pada hari kedua, setiap rumah menyiapkan jedah atau kue yang diperuntukkan pada acara minun kopi atau minum kopi dan badikie atau berdzikir pada malam hari di masjid. Jedah dibuat bertingkat-tingkat dan diisi dengan berbagai macam makanan dan minuman yang biasanya beisikan permen, buah, kue, telur asin, dan lainlain. Jedah yang dibuat oleh masyarakat menandakan bagaimana kondisi ekonomi dari orang tersebut. Semakin berada atau kaya masyarakat yang tinggal di lingkungan Masjid tempat berlangsungnya malamang, maka jedah yang dibuat semakin bagus dan mewah. Kemudian, jedah yang dibuat oleh masyarakat ini dihantarkan oleh menantu perempuan dari ba'da Maghrib atau setelah shalat Maghrib. Malam harinya, dimulailah acara minun kopi atau meminum kopi oleh para pemuda di Masjid dan dilanjutkan dengan badikie yang dipimpin oleh tukang dikie. Jedah yang banyak ini tidak akan habis disantap dan pagi keesokan harinya, para menantu kembali ke Masjid menjemput kue-kue yang sebagian besar tidak dimakan, kemudian membawa kembali ke rumah mertua. 


\section{Gambar 1. Masyarakat Toboh mengantarkan Jamba pada Maulid Nabi di Toboh Olo (11 Februari 2018)}

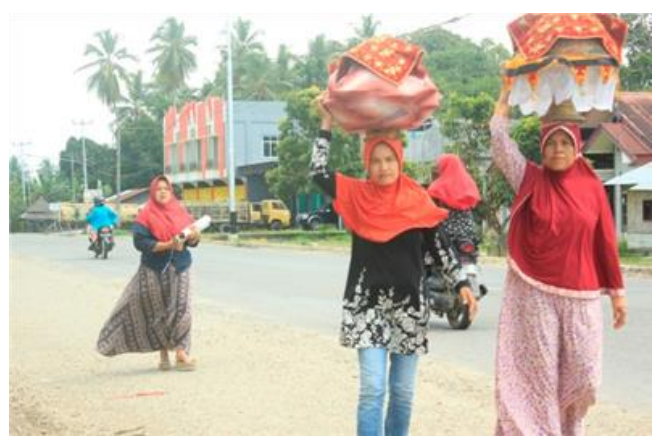

Pada hari ketiga atau puncak kegiatan, mulai dari pagi, ibu-ibu di setiap rumah menyiapkan makananan atau jamba untuk dibawa ke acara bajamba atau makan bersama di Masjid. Jamba adalah hidangan yang diletakkan di atas dulang yang terdiri dari nasi dengan lauk pauknya yang ditutup dengan tudung dan dalamak, terdiri dari nasi dengan lauk pauk seperti ayam singgang, ayam goreng, pangek ikan tongkol yang besar, gulai asam padeh gadang, telur bulat goreng, perkedel, terung goreng, goreng kacang panjang, patai balado. Jenis dan ragam jamba bervariasi disesuaikan dengan kemampuan ekonomi masingmasing masyarakat. Bagi yang mampu atau berada akan menyediakan jamba beragam, mulai dari satu ekor ayam singgang sampai goreng atau pangek ikan besar, di samping ragam sambal lainnya. Bagi yang kurang mampu mungkin hanya membawa satu piring goreng telur dan terung goreng. Jamba disusun bertingkat dalam satu tempat yang disebut umah-umah lalu diantarkan ke Masjid menjelang shalat Dzuhur. Bajamba menjadi ajang untuk saling unjuk kekayaan dengan berlomba-lomba membuat jamba yang lebih besar. Bahkan bisa dikatakan bahwa bagi sebagian lainnya, acara bajamba ini menjadi sebuah kegiatan yang menjurus pada riya. Kegiatan bajamba dilakukan dengan rangkaian kegiatan sebelumnya, yaitu bashalawat dulang dan jamba didoakan oleh Tuangku agar berkah dan makanan yang berlebih bisa dibawa kembali oleh masyarakat untuk keluarganya di rumah. Bajamba yang diadakan di Masjid juga menjadi sebuah kesempatan untuk bertemu dan bercerita dengan teman-teman yang jarang bertemu, termasuk yang pulang dari rantau, ini dapat dipandang merupakan proses sosialisasi nilai-nilai pada generasi yang lebih muda.

Tradisi malamang yang diadakan pada Maulid Nabi ini dilaksanakan oleh masyarakat yang tinggal di sekitar korong tanpa menunggu aba-aba dari pemerintah. Masyarakat secara kelompok membuat kegiatan malamang tetap rutin diadakan setiap tahunnya. Menjelang perayaan Maulid Nabi, para niniak mamak dan alim ulama akan mengadakan suatu pertemuan untuk membahas penyelenggaraan Maulid Nabi yang akan dilaksanakan nanti. Setelah komunikasi kelompok tersebut berjalan, didapat hasil kesepakatan bersama untuk tanggal-tanggal dan lokasi-lokasi yang berbeda-beda untuk setiap perayaan Maulid Nabi di Kabupaten Padang Pariaman.

Masyarakat masih banyak yang beranggapan bahwa tradisi malamang selama ini terlaksana tanpa adanya campur tangan pemerintah. Pemerintah dianggap belum banyak melakukan gebrakan atau rancangan-rancangan baru terhadap kondisi budaya atau tradisi yang ada di tengah-tengah masyarakat. Sebenarnya, Pemerintah Kabupaten Padang Pariaman masih terus melakukan upaya-upaya untuk meyakinkan masyarakat bahwa selama ini pemerintah tengah berusaha untuk membuat program-program kebudayaan yang berkaitan dengan tradisi malamang. Pemerintah juga terus mengkomunikasikan kepada masyarakat tentang posisi pemerintah pada saat kegiatan tradisi malamang, khususnya pada perayaan Maulid Nabi. Rancangan pesan ini perlahan-lahan diharapkan oleh pemerintah agar dapat merubah pandangan masyarakat kepada pemerintah dan pada akhirnya bisa bersama-sama merancang kegiatan Maulid Nabi lebih bagus lagi dari tahun-tahun sebelumnya.

Humas Pemerintah Kabupaten Padang sudah mulai memasukkan unsur-unsur budaya di dalam menjalankan peran serta pemerintah daerah di dalam kegiatan tradisi malamang, hanya saja belum semaksimal yang diharapkan. Humas Pemerintah berintegrasi dengan dinas-dinas yang berkaitan dengan kegiatan tradisi malamang. Salah satu upaya Humas Pemerintah Kabupaten Padang Pariaman ini adalah dengan mengkomunikasikan peran serta pemerintah kepada Dinas Pemberdayaan Masyarakat dan Desa (DPMD) Kabupaten Padang Pariaman. Pemerintah Kabupaten Padang Pariaman melalui 
Humas Pemerintah membentuk pesan-pesan kepada DPMD Kabupaten Padang Pariaman mengenai hal-hal yang menyangkut dengan peran serta pemerintah dalam kegiatan Maulid Nabi yang di sana terdapat warisan budaya yaitu tradisi malamang. Pesan Humas Pemerintah kepada Kepala DPMD isinya adalah DPMD harus bisa menjadi perwakilan pemerintah dalam setiap kegiatan malamang yang diadakan di NagariNagari di Kabupaten Padang Pariaman.

DPMD menjalin komunikasi dengan beberapa tokoh masyarakat dan aktif memberikan masukan-masukan apabila dibutuhkan. DPMD berusaha agar Wali Nagari dapat melibatkan pemerintah dalam acara Maulid Nabi yang rutin dilaksanakan oleh Nagari mereka. Menjelang Maulid Nabi, Wali Nagari mengundang Pemerintah Kabupaten Padang Pariaman ikut bersama masyarakat melakukan perundingan atau musyawarah menentukan tanggal dan lokasi acara Maulid Nabi yang nantinya dilakukan di beberapa korong secara estafet. Setelah disepakati bersama, maka keputusan tadi akan dimasukkan ke dalam kalender masing-masing Kecamatan dan Nagari.

Pemerintah Daerah Kabupaten Padang Pariaman belum berperan serta dalam kegiatan malamang yang dilakukan oleh masyarakat ketika upacara kematian. Setiap kegiatan malamang dalam upacara mendoa kematian, Pemerintah Daerah tidak pernah mengambil bagian dalam kegiatan tersebut. Ini juga mengingat susahnya mendata masyarakat yang mengundang warga untuk medoakan keluarga mereka yang baru saja meninggal. Pemerintah Daerah Kabupaten Padang Pariaman melalui Humas Daerah akan mencoba berkoordinasi dengan Dinas Pemberdayaan Masyarakat dan Desa untuk berperan serta dalam kegiatan-kegiatan kebudayaan yang ada di masyarakat Kabupaten Padang Pariaman, khususnya malamang.

\subsection{Upaya Pemerintah Kabupaten Padang Pariaman dalam Mengkomunikasikan Tradisi Malamang kepada Generasi Muda}

Kegiatan malamang tidak hanya dilakukan oleh orang dewasa saja. Para orangtua mengajak anak-anak mereka sebagai generasi penerus untuk ikut berpartisipasi dalam kegiatan malamang yang diadakan di jorong atau korong mereka. Seperti masyarakat pada umumnya, anakanak diajak ikut serta mencari bambu, daun pisang, daun pandan, kayu bakar, dan membantu orangtua mereka memasak lamang. Bukan hanya membantu secara langsung pada saat membuat lamang, anak-anak juga diajak untuk meramaikan Masjid mereka ketika puncak acara ketika perayaan Maulid Nabi. Hal ini diajarkan dari kecil agar kelak bisa terbiasa sampai dewasa untuk tetap rutin menyelenggarakan tradisi malamang, dan tentu saja meneruskannya kepada penerus mereka nantinya.

Tantangan di zaman sekarang jauh lebih besar dibandingkan zaman-zaman yang sudah berlalu. Salah satunya yaitu kemajuan teknologi yang sangat cepat membuat pola pikir dan kebiasaan masyarakat jauh berbeda dari kebiasaan masyarakat terdahulu. Saat ini generasi muda jauh lebih akrab dengan media sosial yang ada pada handphone mereka dibandingkan dengan sosial masyarakat di lingkungan mereka. Ini menjadi tantangan bagi keluarga dan pemerintah untuk menerapkan pengetahuan tentang kebudayaan kepada generasi muda.

Anak-anak sebagai generasi muda di Kabupaten Padang Pariaman belum banyak mendapatkan pendidikan dan pengajaran mengenai kebudayaan malamang di sekolah. Padahal, pengajaran untuk kebudayaan lokal seperti tradisi malamang perlu mereka dapatkan juga di sekolah agar nantinya tidak melupakan budaya mereka sendiri. Kesadaran dari diri masyarakat memang sangat penting, tetapi perhatian pemerintah kepada pelestarian sebuah tradisi atau budaya juga dapat mempengaruhi bagaimana keberadaan tradisi tersebut untuk beberapa tahun ke depan.

Humas Pemerintah Kabupaten Padang Pariaman merupakan salah satu bagian dari pemerintah yang mempunyai tanggung jawab dalam mengkomunikasikan kebudayaan yang ada di Kabupaten Padang Pariaman kepada generasi muda yang akan menjadi penerus. Humas Pemerintah Kabupaten Padang Pariaman ikut berupaya untuk menanamkan betapa pentingnya ilmu pengetahuan tentang tradisi malamang kepada siswa-siswa sekolah yang ada di Kabupaten Padang Pariaman. Humas Pemerintah Kabupaten Padang Pariaman menyadari bahwa pemerintah belum maksimal dalam membuat program untuk pelestarian tradisi malamang kepada generasi muda. Humas Pemerintah beranggapan bahwa tradisi malamang masih rutin dilakukan oleh masyarakat dari tahun ke tahun, sehingga rasanya anak-anak di sana pasti belajar 
dari orantua mereka mengenai tradisi malamang tersebut.

Penanaman kepedulian kepada tradisi malamang sebenarnya sudah pernah dilakukan oleh sekolah di Kabupaten Padang Pariaman, yaitu di SMA Negeri 1 Lubuk Alung. SMA Negeri 1 Lubuk Alung sudah beberapa kali membuat festival malamang dan bajamba dalam rangka mengenalkan tradisi tersebut kepada generasi muda. Akan tetapi, pada saat ini seluruh SMA sudah menjadi tanggung jawab langsung oleh Dinas Pendidikan dan Kebudayaan Provinsi Sumatera Barat. Pemerintah Provinsi selalu mendukung festival yang dibuat oleh SMA Negeri 1 Lubuk Alung. Meskipun begitu, kegiatan ini tetap menjadi perhatian khusus oleh Pemerintah Kabupaten Padang Pariaman. Pemerintah Kabupaten Padang Pariaman selalu mendukung dan siap membantu apa saja yang dibutuhkan oleh SMA Negeri 1 Lubuk Alung untuk festival malamang dan bajamba.

Dalam rangka mengkomunikasikan tradisi malamang kepada generasi muda, Pemerintah Kabupaten Padang Pariaman memiliki Dinas yang berfungsi untuk menanamkan pendidikan mengenai kearifan lokal kepada pelajar yang ada di Kabupaten Padang Pariaman, yaitu Dinas Pendidikan dan Kebudayaan (Disdikbud). Pemerintah Kabupaten Padang Pariaman melalui Humas Pemerintah membentuk pesan kepada Disdikbud Kabupaten Padang Pariaman mengenai hal-hal yang menyangkut dengan upaya pemerintah dalam pelestarian tradisi malamang. Pesan Humas Pemerintah kepada Kepala Disdikbud isinya adalah Disdikbud harus bisa membuat program penanaman nilai budaya kepada pelajar SD dan SMP di Kabupaten Padang Pariaman melalui pendidikan yang mereka tempuh di sekolah. Pesan ini diteruskan oleh Kepala Bidang Seksi (Kabid) Kebudayaan Disdikbud kepada guru-guru di SD dan SMP di Kabupaten Padang Pariaman untuk tetap mengenalkan kebudayaan-kebudayaan yang dimiliki oleh masyarakat Kabupaten Padang Pariaman.

Pemerintah melalui Disdikbud Kabupaten Padang Pariaman terus berupaya agar generasi muda penerus bangsa ini tidak lupa dengan budaya yang ada di sekitar mereka. Disdikbud memiliki kurikulum mengenai Budaya Alam Minangkabau (BAM) untuk pelajar SD dan SMP. Akan tetapi, BAM yang diajarkan di sekolah berisi tentang seluruh pengetahuan kebudayaan yang ada di Minangkabau, belum fokus pada tradisi malamang. Selain itu, tantangan yang didapati adalah anak-anak lebih mudah menerima apa yang mereka lihat di televisi atau lingkungan mereka yang kini mulai dipengaruhi oleh teknologi modern dibandingkan dengan apa yang diberikan oleh guru mereka. Oleh karena itu, Disdikbud juga berusaha untuk membuat kurikulum baru muatan lokal yang berisi tentang kearifan lokal mengenai tradisi-tradisi yang ada di sekitar Kabupaten Padang Pariaman, termasuk di dalamnya yaitu tradisi malamang. Mereka memiliki target dua atau tiga tahun ke depan, kurikulum kearifan lokal ini akan segera terealisasi

Pesan yang disampaikan oleh Pemerintah Kabupaten Padang Pariaman melalui Humas Pemerintah kepada Disdikbud untuk mulai memperhatikan nilai-nilai budaya yang hampir hilang termakan zaman dan mulai dilupakan oleh generasi muda dapat dikatakan sudah mulai berjalan, walau masih perencanaan-perencanaan. Disdikbud perlu mencermati lagi apa-apa saja yang perlu disajikan di dalam kurikulum kearifan lokal yang ingin dibuat oleh Disdikbud Kabupaten Padang Pariaman. Dengan matangnya persiapan untuk kurikulum ini, maka upaya pemerintah mengkomunikasikan tradisi malamang kepada generasi muda akan berjalan lancar pada tahuntahun selanjutnya.

\subsection{Upaya Pemerintah Kabupaten Padang Pariaman dalam Mengkomunikasikan Tradisi Malamang Menjadi Objek Pariwisata Budaya}

Kegiatan malamang memiliki potensi untuk dikembangkan menjadi salah satu objek pariwisata budaya di Kabupaten Padang Pariaman. Sebagai salah satu warisan budaya yang masih ada dan rutin diselenggarakan setiap tahunnya, kegiatan malamang seharusnya bisa menjadi tujuan para wisatawan yang ingin menyaksikan dan mempelajari budaya di Ranah Minangkabau ini. Selain dapat mempelajari makna budaya yang dimiliki oleh kegiatan malamang, wisatawan juga dapat mempelajari lebih dalam mengenai ajaran agama yang turut berkaitan dengan tradisi tersebut.

Banyak masyarakat dari luar daerah Kabupaten Padang Pariaman mulai datang ke Padang Pariaman untuk sekedar tahu atau belajar mengenai tradisi malamang. Masyarakat secara 
terbuka mengajak pengunjung yang dianggap tamu mereka dan memberi informasi-informasi mengenai tradisi malamang, mulai dari awal saat pembuatan lamang, sampai pada puncak acaranya yaitu bajamba atau makan bersama di Masjid. Ini menunjukkan bahwa masyarakat Kabupaten Padang Pariaman mau menerima siapa saja yang datang ke kampung mereka untuk melihat tradisi malamang. Ditambah lagi, banyak sekali mediamedia lokal yang memberitakan kegiatan malamang, baik itu pada saat adanya perayaan Maulid Nabi atau menyambut Ramadhan.

Pemerintah Kabupaten Padang Pariaman hingga sekarang belum menjadikan kegiatan yang ada pada tradisi malamang menjadi salah satu objek pariwisata budaya yang menarik wisatawan berkunjung ke sana. Pemerintah Kabupaten Padang Pariaman menyadari bahwa pariwisata di Kabupaten Padang Pariaman pada saat ini banyak fokus dalam objek-objek wisata yang bernuansa alam. Objek pariwisata bernuansa alam dianggap cocok untuk para wisatawan yang ingin menikmati pemandangan, berpetualang, atau sekedar mengabadikan tempat wisata mereka ke media sosial.

Pemerintah Kabupaten Padang Pariaman sudah memiliki satu pariwisata budaya dan religius yang banyak diminati oleh masyarakat, yaitu tradisi basafa. Tradisi basafa merupakan salah satu kegiatan ritual keagamaan yang dilakukan oleh umat muslim "Tarekat Syatariyah". Kegiatan ini diadakan rutin setiap tahunnya setiap tanggal 10 Bulan Syafar di Makam Syekh Burhanuddin di Ulakan. Pada saat itu, mereka yang datang akan berbondong-bondong berziarah ke Makam Syekh Burhanuddin. Biasanya, setelah tradisi basafa diadakan kegiatan Maulid Nabi Muhammad SAW yang bagi orang Padang Pariaman disebut dengan Bulan Maulud. Selain itu, Pemerintah Kabupaten Padang Pariaman juga pernah membuat event pariwisata bertemakan budaya dengan mengenalkan malamang kepada pengunjung, yaitu ketika festival Pasia Maelo pada tahun 2015. Pada saat itu, masyarakat diajak bersih-bersih pantai dan beberapa orang membuat lamang untuk dicicipi setelah selesai acara.

Ada beberapa hal yang perlu diperhitungkan dalam memaksimalkan potensi wisata pada tradisi malamang menjadi salah satu objek pariwisata budaya yang ada di Kabupaten Padang Pariaman. Seperti pada tradisi basafa, tradisi malamang sudah rutin dilaksanakan oleh masyarakat di Kabupaten Padang Pariaman selama bertahu-tahun. Rangkaian acara ini sudah jelas urutan dan jadwalnya dari awal sampai akhir acara. Selain itu, kegiatan malamang ini juga tidak habis di satu tempat (korong) saja. Malamang ini berlangsung selama kurang lebih tiga bulan yang dilaksanakan di berbagai tempat dengan jadwal yang berbeda-beda setiap tahunnya. Yang sangat diperlukan oleh pemerintah adalah mengkomunikasikan kepada lembaga-lembaga yang berkaitan mengenai upaya Pemerintah Kabupaten Padang Pariaman menjadikan kegiatan malamang sebagai salah satu objek pariwisata budaya.

Humas Pemerintah merupakan bagian dari pemerintah yang mempunyai tanggung jawab mengkomunikasikan keinginan pemerintah untuk mengembangkan potensi pariwisata budaya pada tradsi malamang kepada masyarakat. Pemerintah Kabupaten Padang Pariaman memiliki dinas yang berfungsi untuk mengembangkan pariwisata yaitu Dinas Pariwisata Pemuda dan Olahraga (Disparpora). Pemerintah Kabupaten Padang Pariaman melalui Humas Pemerintah membentuk pesan-pesan kepada Disparpora mengenai hal-hal yang menyangkut dengan upaya pemerintah dalam mengkomunikasikan tradisi malamang menjadi objek pariwisata budaya. Pesan Humas Pemerintah kepada seluruh anggota yang bekerja di Disparpora, khususnya bidang pariwisata, berisikan informasi bahwa Disparpora harus bisa melihat dan mengembangkan kegiatan kebudayaan menjadi salah satu destinasi wisata yang bisa mendatangkan keuntungan bagi daerah dan masyarakat.

Pemerintah Kabupaten Padang Pariaman tampaknya belum maksimal dalam upaya mereka dalam melihat potensi pariwisata budaya, khususnya malamang. Pesan yang disampaikan Humas Pemerintah kepada Disparpora tidak seiring dengan kebijakan Kepala Daerah atau Bupati yang belum melihat kegiatan malamang sebagai salah satu potensi pariwisata budaya yang bisa dikembangkan. Sebenarnya aktivitas pada tradisi malamang merupakan aktivitas yang sudah "jadi" dan sudah tersusun dengan rapi. Hanya saja, pemerintah belum memikirkan hal-hal-hal lain untuk membuatnya sebagai objek pariwisata budaya, seperti membuat sarana prasarana seperti transportasi, penginapan, atau tempat kuliner bagi wisatawan yang datang ke sana. 
Nilai-nilai budaya kurang mendapat perhatian lebih oleh Pemerintah sebagai prestasi yang harus dibanggakan dan dikembangkan. Untuk pemerhati budaya lokal, orang-orang yang mengenalkan budaya lokal mereka ke nasional atau negara luar, atau siapa saja yang berjasa terhadap pelestarian budaya lokal, mereka bahkan tidak diberi apa-apa sebelum ada media yang meliput mereka. Ini merupakan fenomena umum yang terjadi di negara kita. Walaupun, ada juga beberapa daerah yang malah dikenal dengan kebudayaan yang mereka miliki, bahkan menjadi icon pariwisiata mereka, seperti Grebeg Kraton di Daerah Istimewa Yogyakarta.

\subsection{Implikasi Teoritis dan Praktis Upaya Pemerintah Kabupaten Padang Pariaman dalam Mengkomunikasikan Tradisi Malamang Menjadi Objek Pariwisata Budaya}

Integrasi informasi yang dilakukan oleh Humas Pemerintah Kabupaten Padang Pariaman sebenarnya sudah memiliki metode yang cukup bagus untuk mengkomunikasikan tradisi malamang kepada masyarakat. Pesan tidak langsung disampaikan dari Humas Pemerintah ke masyarakat, melainkan melalui lembaga yang berkaitan dengan informasi yang ingin diberikan. Untuk mengkomunikasikan tradisi malamang, Humas Pemerintah membentuk beberapa pesan yang disampaikan kepada tiga dinas yang berkaitan dengan upaya pemerintah dalam mengkomunikasikan tradisi malamang menjadi objek pariwisata budaya di Padang Pariaman, yaitu Dinas Pemberdayaan Masyarakat dan Desa (DPMD), Dinas Pendidikan dan Kebudayaan (Disdikbud), dan Dinas Pariwisata Pemuda dan Olahraga (Disparpora).

Humas Pemerintah melakukan komunikasi interpersonal dengan Kepala DPMD dan memberikan pesan yang berisi informasi mengenai apa saja peran serta pemerintah dalam setiap kegiatan malamang. Kemudian, Kepala DPMD memberikan informasi kepada anggotanya agar menjadi perwakilan pemerintah untuk menjalin komunikasi dengan setiap Wali Nagari agar melaporkan kepada DPMD setiap menjelang perayaan Maulid Nabi. Kemudian, Humas Pemerintah melakukan komunikasi interpersonal dengan Kepala Disdikbud dan memberikan pesan yang berisi informasi mengenai pentingnya pemerintah memperhatikan tradisi malamang dengan memberikan pengetahuan kepada pelajar SD dan SMP. Kemudian, Kepala Disdiskbud memberikan informasi kepada guru-guru di SD dan SMP di Kabupaten Padang Pariaman agar siswa-siswa diberikan pengetahuan mengenai tradisi malamang. Selain itu, Humas Pemerintah melakukan komunikasi interpersonal dengan Kepala Disparpora dan memberikan pesan yang berisi informasi mengenai keinginan pemerintah mengembangkan potensi pariwisata pada kegiatan malamang. Kemudian, Kepala Disparpora membentuk pesan kepada masyarakat untuk siap menjadikan daerah mereka sebagai salah satu destinasi wisata budaya di Kabupaten Padang Pariaman.

Pengorganisasian pesan yang dibuat oleh pemerintah belum berjalan dengan maksimal. Informasi yang dibuat oleh pemerintah mengenai tradisi malamang belum mampu mencapai valensi positif oleh masyarakat maupun lembaga-lembaga yang ada di bawahnya. Informasi yang dirangkai oleh pemerintah masih kalah dengan pesan informasi yang telah dimiliki oleh masyarakat selama ini mengenai tradisi malamang secara turun-temurun dari keluarga mereka. Pesan yang disampaikan masih terbilang belum memiliki bobot yang kuat untuk membentuk sikap dari masyarakat lebih mengenal dan peduli terhadap pengembangan tradisi malamang menjadi objek pariwisata budaya di Kabupaten Padang Pariaman.

Integrasi informasi antara pemerintah dengan masyarakat dapat berjalan dengan lancar apabila Humas Pemerintah memanfaatkan mediamedia komunikasi seperti koran, majalah, tabloid, atau media sosial sebagai media mereka dalam menyampaikan pesan yang telah mereka bentuk agar sampai dan menimbulkan dampak positif pada masyarakat. Hingga saat ini, pemerintah belum bekerjasama secara intens dengan media terhadap perkembangan tradisi malamang dan potensi pariwisata yang dimilikinya. Media-media meliput dan membuat berita tentang malamang hanya berdasarkan informasi yang didapat dari masyarakat Padang Pariaman.

Pada prakteknya, Humas Pemerintah Kabupaten Padang Pariaman belum menerapkan pendekatan budaya terhadap program-program yang akan dibuat oleh pemerintah. Pendekatan budaya seharusnya sudah mulai digunakan oleh Humas Pemerintah Kabupaten Padang Pariaman mengingat kemajuan teknologi yang pada saat ini bisa memusnahkan kebudayaan-kebudayaan lokal yang semakin tertinggal. Pendekatan budaya 
merupakan alternatif paling bagus yang bisa diterapkan oleh Humas Pemerintah Kabupaten Padang Pariaman dalam mengomunikasikan tradisi malamang baik sebagai pelestarian budaya maupun pengembangan potensi pariwisata budaya. Dengan begitu, Kabupaten Padang Pariaman juga mampu membuat tujuan pariwisata budaya seperti yang diterapkan oleh Yogyakarta pada kegiatan grebeg kraton.

\section{Simpulan}

Kegiatan malamang tidak hanya berkaitan dengan budaya dan ajaran spiritual, melainkan memiliki nilai sosial, kerjasama, dan komunikasi antara komunitas masyarakat dan Pemerintah Daerah dalam etnografi public relations. Malamang masih menjadi rutinitas yang harus dikerjakan dari tahun ke tahun bagi masyarakat yang tinggal di Kabupaten Padang Pariaman. Pemerintah belum mengeluarkan sesuatu yang dapat menjadi penggebrak atau pendorong yang berupa inovasi baru dalam kegiatan tersebut.

Pemerintah Kabupaten Padang Pariaman baru akan memulai untuk mengkomunikasikan tradisi malamang kepada generasi muda. Pemerintah merencanakan adanya kurikulum baru, yaitu muatan lokal "kearifan lokal", yang di dalamnya terdapat ilmu pengetahuan mengenai budaya-budaya lokal seperti tradisi malamang. Sebelumnya, pengetahuan anak-anak yang menjadi generasi penerus mengenai tradisi malamang hanya didapatkan mereka dari keluarga dan lingkungan masyarakat tempat mereka tinggal. Pemerintah Kabupaten Padang Pariaman melalui Dinas Pendidikan dan Kebudayaan terus berupaya mengajarkan bagaimana makna malamang yang sudah menjadi tradisi di Kabupaten Padang Pariaman selama ini.

Kegiatan malamang memiliki potensi untuk dikembangkan menjadi salah satu objek pariwisata budaya di Kabupaten Padang Pariaman. Pemerintah Kabupaten Padang Pariaman belum melihat kegiatan malamang sebagai suatu hal yang harus dikerjakan secara serius dan harus dikembangkan menjadi objek pariwisata budaya yang dapat mendatangkan pendapatan daerah. Pemerintah belum menjadikan pariwisata budaya dalam prioritas program pemerintahan mereka dan dapat mengakibatkan upaya pengembangan tradisi malamang menjadi objek pariwisata di Kabupaten Padang Pariaman dapat berlangsung lama.

\section{Daftar Pustaka}

Alus, Christeward. 2014. Peran Lembaga Adat dalam Pelestarian Kearifan Lokal Suku Sahu di Desa Balisoan Kecamatan Sahu Kabupaten Halmahera Barat. Acta Diurna, 3(4): 1-16.

Hidayat, Dasrun. 2017. Etnografi Public Relations (Tantangan Metodologi Pada Kajian Public Relations Berbasis Budaya). Prosiding Komunikasi, 1(2): 76-87.

Karthago, Abdul Harris. 2014. Peran Dinas Kebudayaan dan Pariwisata dalam Pengembangan Seni Budaya di Kabupaten Bulungan. Ilmu Pemerintahan, 2(1): 19952007.

Littlejohn, Stephen W \& Karen A. Foss. 2009. Teori Komunikasi, edisi 9. Jakarta: Salemba Humanika.

Rahmadi, F. 1999. Public Relations dalam Teori dan Praktek. Jakarta: PT Gramedia Pustaka.

Zulfa dan Kaksim. 2014. Sistem Pola Pewarisan Tradisi Malamang di Kota Padang. Kajian Budaya, 10(20): 57-72. 